\title{
Effects of Exercise and Calorie Restriction on Brain and Testis in Natural Aging Model
}

\author{
Doğal Yaşlanma Modelinde Egzersiz ve Kalori Kısıtlamasının Beyin ve Testiste \\ Etkileri
}

\section{Umay Hakgüder ${ }^{1}$, Ünsal Veli Üstündağ ${ }^{2}$ (D), Burçin Alev Tüzüner ${ }^{3}$ (D), Nevin Genç ${ }^{4}$ (D),

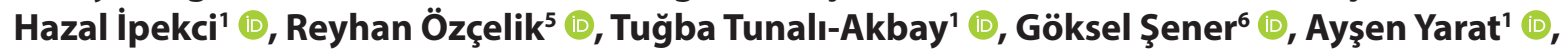 Ebru Emekli-Alturfan ${ }^{1}$ (D)}

\author{
'Department of Biochemistry, Faculty of Dentistry, Marmara University, Maltepe, Istanbul, Turkey \\ 2Department of Biochemistry, Medical Faculty, Istanbul Medipol University, Kavacık, Istanbul, Turkey \\ ${ }^{3}$ Department of Biochemistry, Faculty of Dentistry, Gelişim University, Istanbul, Turkey \\ ${ }^{4}$ Department of Medical Biochemistry, Goztepe Training and Research Hospital, Istanbul Medeniyet University, Istanbul, Turkey \\ 5Department of Pharmacology, Faculty of Pharmacy, Marmara University, Haydarpaşa, Istanbul, Turkey \\ ${ }^{6}$ Vocational School of Health Services, Fenerbahçe University, Istanbul, Turkey
}

\begin{abstract}
ORCID ID: U.H. 0000-0002-0683-4335; Ü.V.Ü 0000-0003-0804-1475; B.A.T. 0000-0001-5122-4977; N.G. 0000-0003-2143-0088; H.I. 0000-0003-1193-168X; R.Ö. 0000-0002-1453-464X; T.T.A. 0000-0002-2091-9298; G.Ş. 0000-0001-7444-6193; A.Y. 0000-0002-8258-6118; E.E.A. 0000-0003-2419-8587
\end{abstract}

Cite this article as: Hakgüder U, Üstündağ ÜV, Tüzüner BA, Genç N, İpekçi H, Ozçelik R, Tunalı-Akbay T, Sener G, Yarat A, Emekli-Alturfan E. Effects of exercise and calorie restriction on brain and testis in natural aging model. Experimed 2021; 11(1): 21-6.

\begin{abstract}
The aim of our study was to examine the effects of exercise and calorie restriction on various tissue damage and antioxidant parameters in the brain and testis of rats in a natural aging model. For this purpose, male Sprague-Dawley rats were the control group (C), the elderly $(A)$, the elderly with calorie restriction (ACR), the elderly who were exercised $(A E)$ and the elderly who were exercised with calorie restriction (ACRE), they were divided into 5 groups. The control group was composed of three-month-old animals. The other group consisted of 15-month-old rats. Exercise and calorie restriction were applied for 6 weeks. At the end of the experiment, lipid peroxidation (LPO), nitric oxide (NO), glutathione (GSH) levels and superoxide dismutase (SOD), catalase (CAT), glutathione-S-transferase (GST) and tissue factor (TF) were determined in brain and testicular tissues homogenates. As a result of the study, the A group's brain and testis LPO, NO levels and TF activity increased, GSH levels and SOD, CAT and GST activities decreased, when compared to the $C$ group. As a result of our study, an increase in oxidant damage was observed with TF activity in the brain and testis in the natural aging model, and positive effects of exercise and calorie restriction on the antioxidant levels in the brain were determined, especially in aging.
\end{abstract}

Öz

Amacımız doğal yaşlanma modelinde egzersiz ve kalori kısıtlamasının sıçanlarda beyin ve testiste çeşitli doku hasarı ve antioksidan parametreler üzerine etkilerinin incelenmesidir. Bu amaçla Sprague-Dawley sıçanlar kontrol (K), yaşlı (Y), kalori kısıtlaması uygulanan yaşlı (YKK), egzersiz uygulanan yaşı (YE) ve kalori kısıtlaması ile egzersiz uygulanan yaşlı (YKKE) olmak üzere 5 gruba ayrıldı. Kontrol grubu üç aylık genç hayvanlardan oluşturuldu. Diğer gruplar 15 aylık sıçanlardan oluşturuldu. Egzersiz ve kalori kısıtlaması 6 hafta boyunca uygulandı. Deney sonunda beyin ve testis dokuları homojenatlarında lipit peroksidasyon (LPO), nitrik oksit (NO), glutatyon (GSH) düzeyleri ile süperoksit dismutaz (SOD), katalaz (CAT), glutatyon-S-transferaz (GST) ve doku faktörü (DF) aktiviteleri tayin edildi. Çalışma sonucunda K grubu ile kıyaslandığında Y grubunda, beyin ve testis LPO, NO düzeyleri ve DF aktivitelerinin arttığı, GSH düzeyleri ile SOD, CAT ve GST aktivitelerinin ise azaldığı gözlendi. Doğal yaşlanma modelinde beyin ve testiste DF aktivitesi ile beraber oksidan hasarda artış gözlenmiş olup, özellikle yaşlanmada egzersiz ve kalori kısıtlamasının beyinde antioksidan düzeyleri üzerinde olumlu etkileri belirlenmiştir.

Anahtar Kelimeler: Yaşlanma, beyin, testis, oksidan, antioksidan

Keywords: Aging, brain, testis, oxidant, antioxidant 


\section{INTRODUCTION}

The aging process is physiologically observed in every living organism, and in this process, an irreversible decline occurs in all functions at the level of tissue, cell and molecule. Among the general signs of aging, a decline can be seen in body functions, adaptation to environmental changes and resistance to harmful factors. In addition, due to aging, changes in cell structure and a decrease in the number of cells and the regeneration ability of the body are observed (1).

Aging is a process that is too complex to be defined by a single mechanism. The biological mechanisms involved alone are not explanatory and are often at the theoretical level. However, not all organs in the organism age at the same rate and no organ ages in the same way in different individuals of the same species. This situation can be explained by individual variations in aging. Today, there are different theories and hypotheses about aging. Increasing oxidative damage has been closely associated with aging and the development of aging-related diseases. Therefore, oxidative stress has an important place in aging and related diseases. Free radicals are molecules produced by aerobic metabolism in a continuous manner and with high proportion. These radicals cause damage in macromolecules such as DNA, proteins and lipids $(1,2)$.

Exercise is defined as all physical activities performed in order to improve and maintain physical and mental health and to gain physical fitness. Exercise, when done regularly, has very important benefits on human health. Exercise improves the functions of circulatory, respiratory, digestive, excretory and skeletal-muscular systems. Inactivity causes various health problems (3). Regular exercise has been associated with a reduction in overall mortality and morbidity in the middle-aged and elderly (4).

Calorie restriction is the limitation of food intake so as not to cause nutritional deficiency, slowing down the aging process. The pathologies associated with aging have also become an important issue in gerontology in recent years. After revealing the relationship between calorie restriction and increase in life span, studies have been conducted on the mechanisms by which calorie restriction regulates aging. The belief that calorie restriction has an "anti-aging" effect, or that it is an antidote to the aging process, has gained wide popularity. However, the relationship between classic calorie restriction and the aging process has not yet been clarified. It is not yet known exactly how to establish optimal food intake for different genotypes (5).

Although aging is an inevitable process, it can be affected by many factors. The ways in which different organs age are also different from each other. Therefore, pathological conditions that cause structural damage and cognitive impairment in the central nervous system during the aging process are also closely related to aging (6). However, the amount of calories taken with nutrition and the level of exercise can be associated with the brain aging through general metabolic activities (7). It has been shown in several studies that oxidative stress can reduce male infertility (8-10). The aim of our study was to examine the effects of exercise and calorie restriction on various tissue damage and antioxidant parameters in the brain and testis in rats in a natural aging model.

\section{MATERIAL AND METHODS}

Sprague Dawley type rats (300-350 g) obtained from Marmara University DEHAMER Animal Laboratory were used in our study. The local ethics committee approved the experimental procedures (130.2013.Mar). The experimental animals were divided into 5 groups. There were 6 rats in the control (C) and aged (A) groups, and 10 rats in the elderly and calorie restriction (ACR) groups, aged and exercise group (AE) and aged group with calorie restriction and exercise (ACRE). The $C$ group consisted of 3month old rats that were fed a standard diet. The A group consisted of 15-month-old rats that were fed a standard diet. The ACR group consisted of 15-month-old rats that were given a calorie restricted for 6 weeks. The AE group consisted of 15-monthold rats that were given swimming exercise for 6 weeks. The ACRE group consisted of 15 -month-old rats that were exercised for 6 weeks with calorie restriction. Calorie restriction was applied by reduction of feeding by $40 \%$ from the standard feed. For exercise, rats were floated for 30 minutes, 3 days a week for 6 weeks in a warm pool of water $\left(25 \pm 2^{\circ} \mathrm{C}\right)$, previously filled with warm tap water. At the end of the 6 weeks experimental period, decapitation was performed under ether anesthesia and the brain and testis tissues were removed and washed with saline. They were cleaned of membranes and veins and divided into small pieces in ice. These small pieces were then cut into minced meat with surgical scissors and weighed. Tissues were homogenized by adding saline $(\mathrm{mL})$ equal to their weight, and tissue homogenates of $10 \%$ were prepared.

To measure the levels of proteins, copper ions were applied to the rats in an alkaline environment. They were then reduced with a phosphomolybdic-phosphotungstic acid reagent (folin reagent). The intensity of the blue color was evaluated spectrophotometrically. The intensity of the blue color formed is proportional to the protein concentration (11). The absorbance of the pink color that was produced at the end of the reaction of the lipid peroxidation (LPO) product malondialdehyde (MDA) and thiobarbituric acid (TBA) was evaluated spectrophotometrically to determine LPO (12). Tissue factor (TF) activity was determined by utilization of the quick method using plasma taken from healthy people. Tissue homogenate is used as a source of tissue factor (Thromboplastin). The time elapsed for fibrin formation after the addition of calcium chloride was determined. Activity varies inversely with time (13). Tissue factor activity is inversely proportional to the time taken for clot formation. To measure nitric oxide (NO) levels, nitrate was converted to nitrite with vanadium (III) chloride. The complex diazonium compound was produced based on the reaction of nitrite sulfanilamide with $\mathrm{N}$ - (1-Naphthyl) ethylenediamine dihydrochloride in an acidic medium. This colored complex formed was measured spectrophotometrically at $540 \mathrm{~nm}$ (14). The colored production of the reaction of Ellman separator, 5-5 'dithiobis 1-2 nitro benzoic acid (DTNB) and sulfhydryl groups was spectrophotometri- 
cally determined for reduced glutathione (GSH) determination (15). superoxide dismutase (SOD) activity was measured as the ability of riboflavin sensitized o-dianisidine to increase the rate of photooxidation (16). Catalase (CAT), activity was determined based on the formation reaction of $\mathrm{H}_{2} \mathrm{O}_{2}$ to $\mathrm{H}_{2} \mathrm{O}$ (17). Glutathione-S-transferase (GST) activity was measured according to the spectrophotometric determination of the $340 \mathrm{~nm}$ absorbance belonging to the product produced by conjugation of GSH with 1-chloro-2,4-dinitro-benzene (CDNB) (18). Analysis of variance (ANOVA) followed by Tukey's multiple comparison test were used for statistical analysis (GraphPad Prism 9.0, California, USA).

\section{RESULTS}

\section{Brain Tissue}

GSH values in brain tissue were decreased in A and ACR groups when compared with the controls. Compared to the A group, it was increased in the ACR, AE and ACRE groups. GSH values were increased in the ACRE group compared with the ACR group. SOD activity was significantly decreased in the $A, A E$, $A C R$ and ACRE groups compared to the controls. In comparison with the $A$ group, it was increased significantly in the $A E$, $A C R$ and ACRE groups. CAT activity was decreased in the $A, A E$ and $A C R$ groups when compared to the $C$ group, and it was increased significantly in the ACRE group compared with the A group. GST activity was decreased in the A group in comparison with the $C$ group, and significantly increased in the ACRE group compared with $A$ and AE groups (Figure 1). LPO was increased significantly in A and AE groups compared to the $C$ group. LPO was decreased significantly in the ACR group compared with the A group. Brain TF activity was increased significantly in $A, A E$ and $A C R E$ groups compared with the $C$ group. NO values were increased significantly in the $A, A E$ and
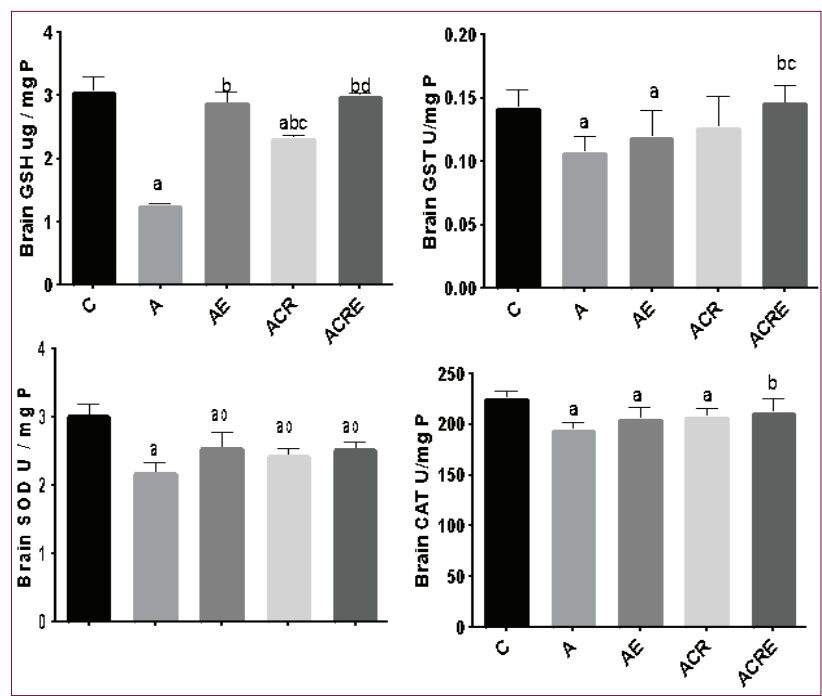

Figure 1. Brain GSH levels, GST, SOD and CAT activities of the groups. ${ }^{a} p<0.05$ significantly different than the $C$ group; ${ }^{b} p<0.05$ significantly different than the A group; ${ }^{c} p<0.05$ significantly different than the AE group; ${ }^{d} p<0.05$ significantly different than the ACR group.
ACRE groups compared with the $C$ group. Compared to the $A$ group, NO values was decreased in the ACR group. NO values were increased in the ACRE group compared with the ACR and A groups (Figure 2).
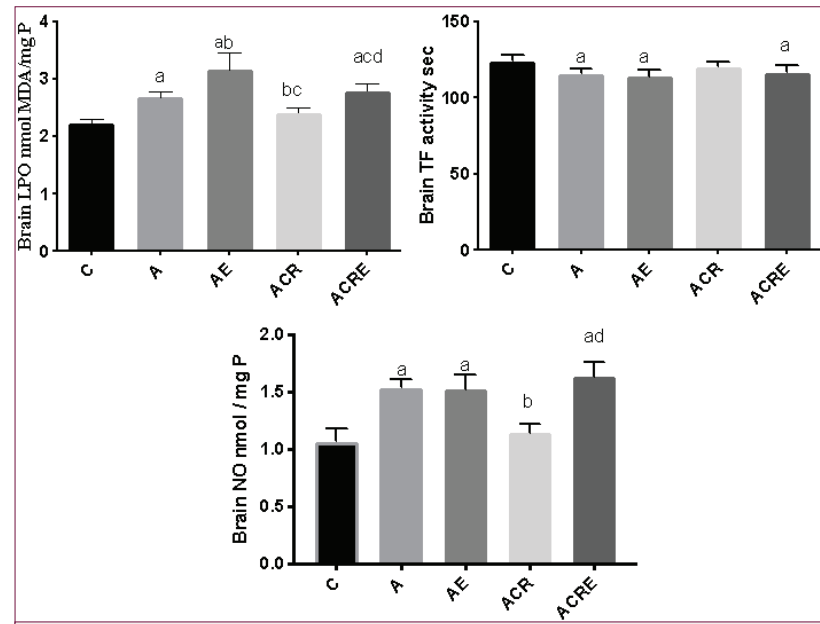

Figure 2. Brain LPO, NO levels, and TF activities of the groups. ${ }^{a} \mathrm{p}<0.05$ significantly different than the $C$ group; ${ }^{b} \mathrm{p}<0.05$ significantly different than the A group; ${ }^{c} p<0.05$ significantly different than the $A E$ group; ${ }^{d} p<0.05$ significantly different than the ACR group.

\section{Testis Tissue}

Testis GSH levels were decreased significantly in the $A, A E, A C R$ and ACRE groups, compared to the $C$ group. There was a significant increase in the GSH levels of ACRE group compared with
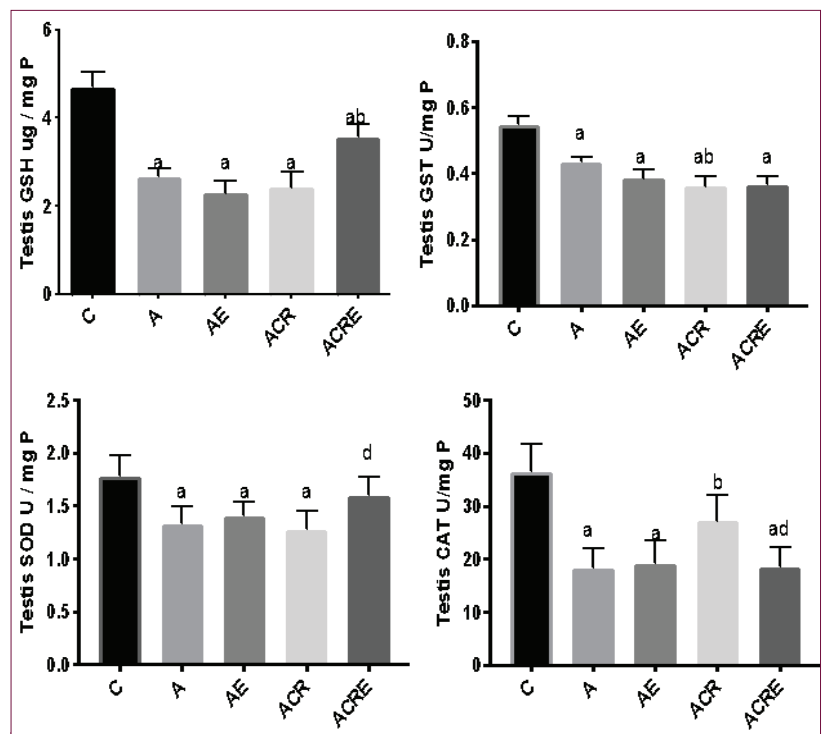

Figure 3. Testis glutathione levels, GST, SOD and CAT activities of the groups. ${ }^{a} p<0.05$ significantly different than the $C$ group; ${ }^{b} p<0.05$ significantly different than the A group; ${ }^{c} p<0.05$ significantly different than the AE group; ${ }^{d} p<0.05$ significantly different than the ACR group. 
the $C$ and $A$ groups. SOD activity was decreased significantly in the $A, A E, A C R$ groups compared with the $C$ group, and was also increased significantly in the ACRE group compared with the ACR group. CAT activity was decreased significantly in the $A, A E$, and $A C R E$ groups compared to the $C$ group, and increased significantly in the ACR group compared with the $A$ group. GST activities were decreased significantly in the $A, A E$, $A C R$ and $A C R E$ groups compared with the $C$ group (Figure 3 ). LPO was increased significantly in the A group compared with the $C$ group, and was decreased significantly in the $A E, A C R$ and ACRE groups compared with the A group. In the ACRE group LPO was also decreased in comparison with the $A, A E$ and ACRE groups. TF was increased significantly in the $A, A E, A C R$, and ACRE groups compared with the $C$ group. NO levels were increased significantly in the $A, A E$ and $A C R$ groups compared with the $C$ group, and were decreased significantly in the $A E$ and ACRE groups compared with the A group (Figure 4).

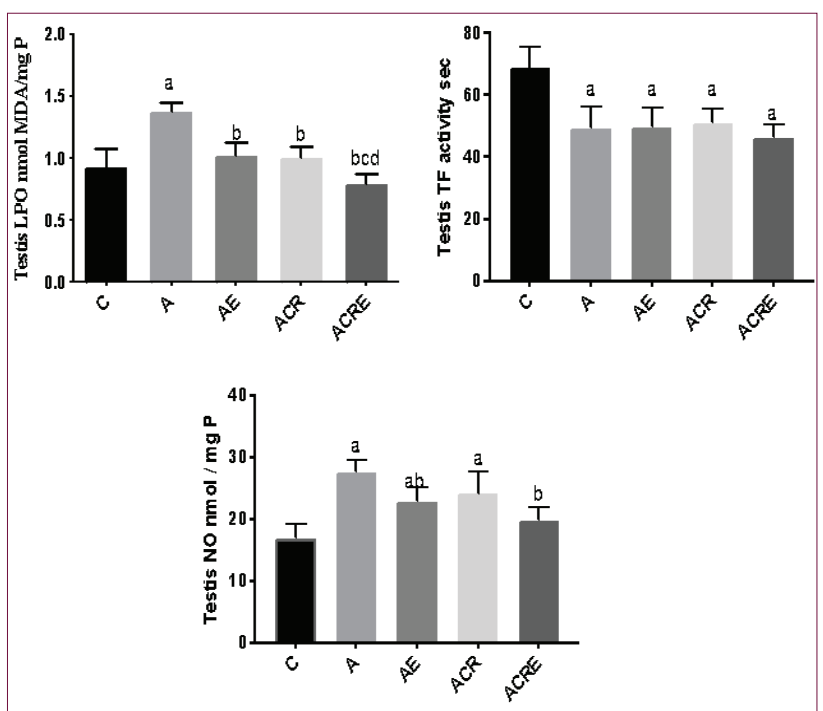

Figure 4. Testis LPO, NO levels, andTF activities of the groups. ${ }^{a} \mathrm{p}<0.05$ significantly different than the $C$ group; ${ }^{b} \mathrm{p}<0.05$ significantly different than the A group; ${ }^{c} p<0.05$ significantly different than the $A E$ group; ${ }^{d} p<0.05$ significantly different than the ACR group.

\section{DISCUSSION}

As a result of our study, LPO, NO levels and TF activity were found to have increased in the brain and testicular tissues of the elderly group compared with the control group. The GSH levels and SOD, CAT and GST activities were found to have decreased. Compared with the elderly group, LPO, NO levels and TF activity were decreased, and GSH and SOD activity were increased in the brains of the elderly group with calorie restriction. LPO and GSH levels and SOD activity were increased in the elderly group that was exercised. SOD, CAT and GST activities were increased in the elderly group that were exercised together with calorie restriction compared to the elderly group. Compared to the elderly group, LPO and NO decreased in the testicles of the elderly group with exercise and calorie restriction, while calorie restriction increased CAT activity and decreased GST activity in the elderly group.

Although the basic principles and mechanisms of aging have not been fully elucidated, there are various theories on this issue. Increasing oxidative damage has been closely associated with aging and the development of aging-related diseases (19). Therefore, oxidative stress has an important place in aging and related diseases. Free radicals are molecules produced by aerobic metabolism in a continuous manner, with high proportion. These radicals cause damage to macromolecules such as DNA, proteins and lipids (20).

As the redox balance deteriorates with aging, more free radicals are formed. Oxidative protein damage due to increased oxidative stress may cause changes in the structure of proteins such as aggregation, fragmentation, and secondary / tertiary structure. All these changes may cause both susceptibilities to proteolysis and changes in the normal function of proteins (19).

With the emergence of the relationship between free radicals and aging, the search for a diet that reduces or stops oxidative stress has come to the fore. It has been shown that antioxidant-rich diets result in less weight gain and tumor formation in experimental animals and reduce autoimmune diseases (21).

Older animals were shown to have more mitochondrial reactive oxygen species (ROS) than young animals. Oxidative DNA damage is cited as one of the most significant causes of aging. ROS could cause damage to the sugar-phosphate skeleton in DNA and can also cause point mutations on bases (22).

With aging, oxidative mitochondrial DNA (mtDNA) damage occurs in striated muscles, heart muscles and the brain. The importance of oxidative mtDNA damage and related mutations in the aging process has been emphasized in various studies, and it has been shown that mitochondria plays a major role in aging. There are antioxidant defense systems that protect against oxidative damage in the organism. Whether the antioxidant defense systems in the tissues are more active depending on the ROS produced continuously in the long-lasting species or not is a separate research subject. A study found a relationship between SOD activity in the liver, brain and heart tissues and the maximum lifespan in 14 mammal species (23).

The effects of aging on the testicles in rats were studied. Testicular sections taken from 3, 6 and 24 month old rats were examined morphologically, and it was reported that Leydig cells and collagen fibers in the testicular interstitium were more common in 6-24 month old rats than in 3 month old rats. It has also been shown that macrophages are greater in 6 month old rats than in 3 and 24 month old rats. Testosterone and luteinizing hormone (LH) levels did not differ between 3 and 6 month old rats, but it was reported to be lower at 24 months (24).

In a study examining the antioxidant activities of rat testis, it was suggested that the testicular antioxidant system is differ- 
ent from the liver. The most significant difference was reported as high SOD activity in the testis of 6-10 day old rats, and low CAT and GSH-Px activity in the testis. It has been suggested that this high SOD ratio will make the testicles more susceptible to prooxidant factors. However, non-enzymatic antioxidants are also important in the defense system, but were not investigated in this study. The greatest difference in antioxidant enzyme activities in testicles was determined between 20-30 day old rats and it has been reported that this difference may be due to the change in testicular structure. Fetal type Leydig cells are replaced by adult Leydig cells shortly after birth. Antioxidant enzyme activities have been reported in different testicular cells. For example, SOD and GST activity is high in Sertoli cells. The reason for the high SOD activity in young rats has been defined as the increased need for hydrogen peroxide, which has not yet been fully elucidated in some developmental processes. Hydrogen peroxide has been shown to stimulate prostaglandin synthesis in the renal glomerulus in rats. Hydrogen peroxide has also been shown to stimulate cell differentiation. The high SOD activity seen in the early stages of life has been associated with the role of hydrogen peroxide in cell differentiation (25).

Only two known forms of SOD, cytosolic (Cu/Zn) and mitochondrial (Fe/Mn), are not found in the testicles. Testis also contain extracellular SOD that is generated by the sertoli and germ cells. It is well known that cytokines such as interleukin 1a stimulate extracellular superoxide dismutase (SOD-Ex) release in Sertoli cells (26).

It has been reported that catalase does not have much effect on the testis, and GPx, which uses GSH as an electron source to reduce $\mathrm{H}_{2} \mathrm{O}_{2}$ to water, has different isoforms in this tissue. GPx has been detected in mitochondria, nucleus and spermatozoa. Since many forms of GPx are selenium dependent, selenium deficiency affects male reproductive health negatively (27). It has been reported that physical exercise increases testis antioxidant enzyme activities in aged rats and may delay the effects that may occur on the testis with aging (28). In addition, it has been suggested that moderate exercise has a healing effect against oxidative damage in the testis due to chronic ethanol consumption (28).

However, it has been shown that excessive exercise increases lipid peroxidation in the testicles and can decrease antioxidant enzyme activities including CAT, SOD, and GST (29). The resulting stress can inhibit both steroidogenesis and germ cell differentiation in testis. The improvement of these effects when alpha tocopherol was administered as an antioxidant showed that exercise-induced testis dysfunction was associated with oxidative stress (30).

Aging is a biological process seen in all living organisms. Anatomical and physiological processes that occur with aging affect the development and outcome of some diseases. With the increase of the elderly population in the world, it is increasingly necessary to develop treatment programs for a better quality of life and prevention of diseases in this process. In the aging brain and various neurodegenerative diseases, there is a decline in normal antioxidant defense mechanisms, which increases the vulnerability of the brain to the harmful effects of oxidative damage. For example, the antioxidant enzymes SOD, CAT, GPx and glutathione reductase show reduced activities in the brains of patients with Alzheimer's disease (19).

Calorie restriction has been evaluated as the only reproducible experimental manipulation to increase life expectancy in many species. Restriction of nutrient intake below $30 \%$ to $50 \%$ of ad libitum levels during the early growth phase of life has been shown to result in significant increases in life expectancy of a variety of species, including insects, mice, fish, and rats (30).

In the literature, increased oxidative stress and inflammation with aging have been associated with an increase in TF expression $(32,33)$. As a result of our study, increased TF activity in the brain and testis in the natural aging model was related to increased oxidant damage and inflammation with age. Especially in aging, calorie restriction is associated with TF and the mechanism of its positive effects on NO needs to be elucidated.

Oxidative stress is closely related to the pathology of many diseases, especially aging, cancer, heart diseases and diabetes. For a quality and long life, all the functioning and repair mechanisms of the organism must work completely. Although acute physical activity has been shown to increase oxidative stress, regular physical activity has shown positive effects on aging-related diseases by strengthening antioxidant defense systems. In our study, the effects of calorie restriction, especially in reducing oxidative stress in the brain and strengthening antioxidant defense systems, were observed. Although calorie restriction can be considered as a way to increase functional lifespan, nowadays, there is evidence that choosing whole foods in a balanced way or addition of antioxidants to the diet is beneficial for a longer functional life span.

Ethics Committee Approval: All the experimental procedures wereapproved by the Institutional Animal Care and Use Committee of Marmara University (130.2013.Mar).

Peer-review: Externally peer-reviewed.

Author Contributions: Concept - E.E.A., G.Ş.; Data Collection - A.Y., T.T.A.; Data Analysis and/or Interpretation - U.H., Ü.V.Ü., H.I.., B.A., R.Ö., N.G.K.; Writing - E.E.A.

Conflict of Interest: The authors have no conflict of interest to declare.

Financial Disclosure: This study was supported by the Marmara University Scientific Research and Project Commision (Project No: SAG-CYLP-131217-0662).

Etik Komite Onayı: Tüm deneysel prosedürler Marmara Üniversitesi Kurumsal Hayvan Bakım ve Kullanım Komitesi tarafından onaylanmıştır (130.2013.Mar).

Hakem Değerlendirmesi: Dış bağımsız. 
Yazar Katkıları: Çalışma Konsepti - E.E.A., G.Ş.; Veri Toplama - A.Y., T.T.A.; Veri Analizi/Yorumlama - U.H., Ü.V.Ü., H.I., B.A., R.Ö., N.G.K.; Yazma - E.E.A.

Çıkar Çatışması: Yazarlar çıkar çatışması bildirmemişlerdir.

Finansal Destek: Bu çalışma Marmara Üniversitesi Bilimsel Araştırma ve Proje Komisyonu tarafından desteklenmiştir (Proje No: SAG-CYLP-131217-0662).

\section{REFERENCES}

1. Ergün M. Yaşlılık ve Egzersiz. TJSM 2013; 48:131-8.

2. Hawkins SA, Wiswell RA, Marcell TJ. Exercise and the master athlete-a model of successful aging? J Gerontol A Biol Sci Med Sci 2003; 58: 1009-11. [CrossRef]

3. Wilmore J, Knuttgen $\mathrm{H}$. Aerobic exercise and endurance improving fitness for health benefits. Phys Sportsmed 2003; 31(5): 45. [CrossRef]

4. Blair SN, Kohl HW 3rd, Paffenbarger RS Jr, Clark DG, Cooper KH, Gibbons LW. Physical fitness and all-cause mortality. A prospective study of healthy men and women. JAMA 1989; 262: 2395-401. [CrossRef]

5. Sohal RJ, Forster MJ. Caloric restriction and the aging process: a critique. Free Radic Biol Med 2014; 73: 366-82. [CrossRef]

6. Segura B, Jurado MA. Metabolic syndrome and ageing: cognitive impairment and structural alterations of the central nervous system. Rev Neurol 2009; 49(8): 417-24. [CrossRef]

7. Polat F, Kumral E. Normal ve patolojik beyin yaşlanması. Ege J Med 2010; 49(3): 3-10.

8. Holmes RP, Goodman HO, Shihabi ZK, Jarow JP. The taurine and hypotaurine content of human semen. J Androl 1992; 13(3): 28992.

9. Aitken RJ. Free radicals lipid peroxidation and sperm function. Reprod Fertil 1995; 7(4): 659-68. [CrossRef]

10. Aitken RJ, Deluliis GN. On the possible origins of DNA damage in human spermatozoa. Mol Hum Reprod 2010; 16(1): 3-13. [CrossRef]

11. Lowry OH, Rosebrough NJ, Farr AL, Randall RJ. Protein measurement with folin phenol reagent. J Biol Chem 1951; 193: 265-75. [CrossRef]

12. Ledwozyw A, Michalak D, Stepien A, Kadziolka A. The relationship between plasma triglycerides, cholesterol, total lipids and lipid peroxidation products during human atherosclerosis. Clin Chim Acta 1986; 155: 275-83. [CrossRef]

13. Ingram GIC, Hills M. Referance method for the one stage prothrombin time test on human blood. Thromb-Haemostas. 1976; 36: 237-8. [CrossRef]

14. Miranda KM, Espey MG, Wink DA. A rapid, simple spectrophotometric method for simultaneous detection of nitrate and nitrite. Nitric Oxide 2001; 5(1): 62-71. [CrossRef]
15. Beutler E. Glutathione in red cell metabolism. In: A manuel of biochemical methods. 2nd ed, Grune and Stratton, NY,1975. p. 112-4.

16. Mylorie AA, Collins H, Umbles C, Kyle J. Erythrocyte superoxide dismutase activity and other parameters of cupper status in rats ingesting lead acetate. Toxicol Appl Pharmacol 1986; 82: 512-20. [CrossRef]

17. Aebi H. Catalase In vitro. In: Methods of Enzymatic Analysis. Ed: Bergmeyer HU, 2nd ed, FL,1974, p.121-6.

18. Habig WH, Jacoby WB. Assays for differentation of glutathione-stransferases. Methods Enzymol 1981; 77: 398-405. [CrossRef]

19. Gemma C, Vila J, Bachstetter A, Bickford PC. Oxidative stress and the aging brain: from theory to prevention. In: Riddle DR, editor. Brain Aging: Models, Methods, and Mechanisms. Boca Raton (FL): CRC Press/Taylor \& Francis; 2007. Chapter 15. [CrossRef]

20. Devi SA, Kiran TR. Regional responses in antioxidant system to exercise training and dietary vitamin $\mathrm{E}$ in aging rat brain. Neurobiol Aging 2004; 25(4): 501-8. [CrossRef]

21. Sacher GA. Life table modification and life prolongation. In: Handbook of the biology of aging. Ed. Finch, CE., Hayflick, L. New York, Van Nostrand, 1977.p. 582-638.

22. Demirsoy A. Yaşlanmanın ve ölümün evrimsel öyküsü. Geriatri 1998; 1(1):1-12.

23. Tolmasoff JM, Ono T, Cutler RG. Superoxide dismutase: correlation with life span and specific metabolic rate in primate species. PNAS. 1980; 77: 2777-81. [CrossRef]

24. Mendis-Handagama SM, Gelber SJ. Signs of aging are apparent in the testis interstitium of Sprague Dawley rats at 6 months of age. Tissue Cell 1995; 27(6): 689-99. [CrossRef]

25. Peltola V, Huhtaniemi I, Ahotupa M. Antioxidant enzyme activity in the maturing rat testis. J Androl 1992; 13(5): 450-5.

26. Mruk DD, Silvestrini B, Mo MY, Cheng CY. Antioxidant superoxide dismutase- $A$ review: Its function, regulation in the testis, and role in male fertility. Contraception. 2002; 65: 305-11. [CrossRef]

27. Kaur $P$, Bansal MP. Influence of selenium induced oxidative stress on spermatogenesis and lactate dehydrogenase- $X$ in mice testis. Asian J Androl 2004; 6: 227-32.

28. Somani SM, Husain K. Exercise training alters kinetics of antioxidant enzymes in rat tissues. Biochem Mol Biol Int 1996; 38: 587-95.

29. Manna I, Jana K, Samanta PK. Intensive swimming exercise-induced oxidative stress and reproductive dysfunction in male wistar rats: Protective role of alpha-tocopherol succinate. Can J Appl Physiol 2004; 29: 172-85. [CrossRef]

30. Masoro EJ. Caloric restriction and aging: an update. Exp Gerontol 2000; 35: 299. [CrossRef]

31. Cho Y, Cao X, Shen D, Tuo J, Parver L M., Rickles F R, et al. Evidence for enhanced tissue factor expression in age-related macular degeneration. Lab Invest 2011; 91(4): 519-26. [CrossRef]

32. Kazachkova N. Aging and Thrombosis: The Role of Genetic Factors. J Blood Disord 2016; 3(1): 1040. 